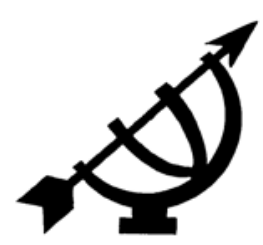

\title{
Traces of neo-Calvinism in France and Italy
}

\author{
R. Coletto \\ School of Philosophy \\ Potchefstroom Campus \\ North-West University \\ POTCHEFSTROOM \\ E-mail: renato.coletto@nwu.ac.za
}

\section{Abstract: \\ Traces of neo-Calvinism in France and Italy}

This article deals with the history of the neo-Calvinist movement in France and Italy. The efforts of the Dutch Reformational movement to communicate with French (mainly reformed) Christians are highlighted. A brief overview of the achievements of the few French scholars involved in this development is sketched and their publications are mentioned, together with a few conferences and organisations. Neo-Calvinism reached Italy as well, via the input of French lecturers and publications. The few developments of neo-Calvinism in Italy are recorded as well. Also, the gradual drift towards vantilian and reconstructionist positions (in both countries) is detected and discussed. An evaluation of these developments is provided, together with a few final considerations and questions which should help learning lessons from the past and preparing better strategies for the future.

\section{Opsomming}

\section{Spore van neo-Calvinisme in Frankryk en Italië}

Hierdie artikel handel oor die geskiedenis van die neoCalvinistiese beweging in Frankryk en Italië. Die pogings van die Nederlandse Reformatoriese beweging om met Franse (hoofsaaklik reformatoriese) Christene te kommunikeer, word belig. 'n Kort oorsig van dit wat enkele Franse geleerdes in hierdie ontwikkeling bereik het, word geskets en hulle publikasies word genoem, asook enkele konferensies en organisasies. Die neo-Calvinisme het Italië bereik as gevolg van die 
pogings van Franse dosente en publikasies. Die enkele ontwikkelings van neo-Calvinisme in Italië word ook weergegee. Die geleidelike beweging na Van Tiliaanse en rekonstruksionistiese posisies (in albei lande) word ook uitgewys en bespreek. 'n Evaluering van hierdie ontwikkeling word gegee, asook enkele finale oorwegings en vrae wat behoort te help wanneer lesse uit die verlede geleer moet word en beter strategië vir die toekoms voorberei word.

\section{Introduction}

The Society for Calvinist Philosophy in the Netherlands (now Society for Reformational Philosophy) has completed 75 years (1935-2010) of activities, a period in which it has successfully promoted Christian philosophising in five continents. This is an occasion for celebration and thankfulness, and to reflect on the history of the neo-Calvinist movement (with special attention to its reformational $\mathbf{1}$ branch). The latter is not only interested in philosophy, of course. During its life it has been busy with education and politics, art and agriculture, labour, business and so on. Nevertheless, one can surely say that the Society for Calvinist Philosophy has played a strategic role for the promotion of Christian scholarship all over the world.

This article deals with a small section of this history: the "traces" of neo-Calvinist scholarship in France and Italy. ${ }^{2}$ Nevertheless, it is gratefully dedicated to Professor Bennie van der Walt, ambassador of Christian Scholarship in five continents. In my opinion, Van der Walt's openness to the international dimension of this mission, his knowledge of the (worldwide) field, his readiness to cross cultural barriers and his effectiveness in popularising and spreading refor-

1 I use the term reformational to indicate scholars, texts, ideas, approaches particularly tuned in with the philosophy of Dooyeweerd, Vollenhoven and their successors. The term vantilian refers to scholars and approaches tuned to the work of Cornelius Van Til. Reconstruction/ist refers to the particular branch of authors/views related to Rousas John Rushdoony, Gary North, Greg Bahnsen and so on. Finally, the term neo-Calvinist (synonym of kuyperian) includes all the above-mentioned groups.

2 All translations appearing in this text, whether from French, Italian or Latin are by the author. The bibliographic details in the original languages are given in the final "List of references", while to facilitate the reading, English translations (of titles, journal names, etc.) are provided in the text. Translations are neglected when the meaning of the (French) phrase/s can be easily guessed by English and Afrikaans-speaking readers. 
mational ideas all over the globe are unsurpassed (and I suspect it will remain so for quite a while).

In the following article I will focus especially on the reformational and vantilian movements, while I will leave aside the more recent "traces" of the Plantinga-Wolterstorff school of thought (also known as "Reformed Epistemology"). This choice has a few reasons. Firstly an English article by Di Gaetano (2005) supplying information on the reception of this philosophical school in the Italian context has already seen the light. Secondly, this movement does not yet have, to my knowledge, a broad support base in the protestant communities of France and Italy. Finally, some of the representatives of this school would not regard themselves as "full members" of the kuyperian philosophical family, and this should be respected.

The choice of focusing on France and Italy is also due to several reasons. First of all I myself have lived in Italy up to the age of 36 and I have, therefore, "first-hand" experience of some of the events recalled here. Secondly, the developments of neo-Calvinism in these two countries are inter-related and lastly, I am not aware of any document already written on this topic.

The main questions underlying the presentation of this history are: what can be learnt from those past events? What are their causes? Can they help clarifying the dangers and the needs for the future promotion of Christian scholarship? I will not provide clear-cut answers, but I will attempt a few hypotheses and suggestions. My strategy will consist in sketching a history of neo-Calvinism in these two countries, then I will also attempt an interpretation and evaluation.

\section{What has neo-Calvinism to do with France and Italy?}

Where can one trace the first contacts between Dutch neo-Calvinists and French or Italian individuals or communities? When the reader tries to recall any significant contact, the first reaction may well be one of perplexity. Were there any contacts at all? Thinking a bit deeper though, some might remember that Groen van Prinsterer wrote several texts in French. But that was before Kuyper. Is that all? And what about Italy?

Yet, an early connection emerges when the question is reversed: did French-speaking Calvinists have anything to do with the Dutch Reveil which is the cradle of neo-Calvinism? One more touch: to find this early connection one has to add to the picture the (francophone) 
city of Geneva. Following this path one discovers that, among the persons who influenced Groen van Prinsterer and made him the leader he became, there were several French-speaking ministers, the most important of whom was Henri Merle d'Aubigné, from Geneva.

The latter was appointed Chaplain of the royal Dutch court in 1823 (Freeke, 2001:129). It was through the preaching and personal advice of this minister (and of a few others) that Van Prinsterer was encouraged to persevere in his faith, to resist both secularism and liberalism, to consolidate his belief and finally to become the precursor and mentor of Abraham Kuyper.

Merle d'Aubigné had been strongly influenced by the Swiss Reveil which had its centre in Geneva. He attended the community of La Pélisserie, situated in Bourg du Four, which was the centre of such fervid spiritual reveil.

Here the link with Italy emerges as well. It was here, in the 1850s, that a small community of Italian exiles was introduced to protestant ideas and was converted to the new faith. When the events allowed them to return to Italy, they were the founders of the Chiese Libere (Free Churches) shaped on the model of Geneva's Free Churches (Maselli, 1974:35-52). It was precisely among the "descendants" of those churches, 120 years later, that a strong interest for neo-Calvinist ideas emerged. In the 1970s traces of neo-Calvinism appeared in small sectors of Italian evangelicalism, also through the input of French protestants of reformed convictions (see section 6.1 and 6.2 below).

These links should be sufficient at least to see that the events we are going to explore are not simply or totally unrelated. From now on we will limit our research to the period following the establishment of the Society for Calvinist Philosophy, i.e. from 1935.

\section{Reformational outreach towards France}

For the first few years after the establishment of the Society for Calvinist Philosophy, there was almost no single text written by (Dutch) reformational scholars in a language other than Dutch. ${ }^{3}$ As

3 There were, however, texts written in other languages by (non-Dutch) reformational authors. See for example Marcel (1937), Scotus' conception of the law, published in the Netherlands. Outside of the Netherlands there were of course texts in Afrikaans. It is also interesting to take note of Kuyper's article 
Dengerink (who speaks French quite well) observes, during the 1930s there was only one such text - written in German in 1939 (Dengerink, 1994:109). 4 The years after 1946, however, saw a renewed interest for exporting into new countries the ideals of reformational scholarship. In 1947, Dooyeweerd's first article in English was published (Dooyeweerd, 1947). Originally, it was a lecture delivered to French students in Amsterdam and it was published in French one year later (Dooyeweerd, 1948). In the 1950s Dooyeweerd travelled to the United States and South Africa and held several conferences.

He travelled to France as well. In 1951 and 1952 he participated in the Franco-Dutch meetings of the Chateau de Paron, organised by the Societé Calviniste de France. Other visits followed. Some of his lectures became articles and were published in French. The following examples do not aim at historical completeness, but are illustrating the new "missionary" awareness of the Dutch reformational movement.

A lecture held in 1953 at the universities of Aix-en-Provence and Marseille was published in French one year later in Philosophia reformata 5 (Dooyeweerd, 1954a). There Dooyeweerd commented on the views of the famous Christian philosopher of Aix-en-Provence, Maurice Blondel (The problem of Christian philosophy: a comparison between Blondel's philosophy and the new reformed philosophy in the Netherlands).

Several other articles were published by La revue réformée, 6 starting from "The secularisation of science" (Dooyeweerd, 1954b), which reflects a report presented at the Sixth International Reformed Congress in Montpellier. Then followed Philosophy and theology (Dooyeweerd, 1958a), originally a lecture delivered in 1957 at the Faculty of Theology of the University of Paris. Progressive and re-

(1907) written for the French public: The separation. This article deals with the separation of church and state in France and was published in the Journal des débats.

4 Dengerink omits the author of the article, but gives a few bibliographical details: "Das natürliche Rechtsbewusstein und die Erkenntnis des geoffenbarten göttlichen Gesetzes". Antirevolutionaire staatkunde, 13:157-182.

5 This journal is the official organ of the Society for Calvinist Philosophy in the Netherlands.

6 Journal of the Free Faculty of (reformed) Theology of Aix-en-Provence. 
gressive movements in history (Dooyeweerd, 1958b) was first presented in 1957 at the Faculty of Letters of the same university.

The Five conferences (Dooyeweerd, 1959) were held at the Social Museum of Paris in December 1957. This text, in five parts, constitutes a good introduction to Dooyeweerd's philosophy (about its further translation into Italian see section 6.2 below). ${ }^{7}$ Apart from Dooyeweerd, two publications in French were delivered by Mekkes (1953; 1965), one by Zuidema (1953) and one by Vollenhoven (1953). 8

In 1965, when a honorary volume was dedicated to Dooyeweerd (De Gaay Fortman, 1965) one could see that reformational philosophy was not simply a Dutch "business" anymore. Of the 29 contributions dedicated to Dooyeweerd, ten were written in a language other than Dutch and six of these were in French. Some of the French texts were written by Dutch authors (which testifies of their interest for the francophone public). The volume, however, included the contributions of some French authors as well. Among those who shared Dooyeweerd's views was André Schlemmer (1965), a medical scholar who wrote Medical science and the unity of man. Among the colleagues was Jacques Ellul (1965), a member of the Église Réformée de France (Reformed Church of France). ${ }^{9}$

\section{French responses: the first phase}

The French protestant community did not remain indifferent to neoCalvinist ideas. France is a country in which the Reformation was repressed in the massacre of the night of St. Bartholomew (23-24 August, 1572). Thousands of Huguenots were killed and Calvinism could never "recover fully". However, a (numerically modest) protestant community is still present today. Concerning the French evan-

7 Translated in English, the titles of the five conferences are: The so-called autonomy of theoretical thought; The basis of Greek philosophy; The basis of scholastic philosophy; The basis of humanist philosophy; The new task of a Christian philosophy.

8 Transcendental critique of theoretical thought (Mekkes, 1953); Time (Mekkes, 1965); Reformed conception of life (Zuidema, 1953); The developments of Aristotle: a study on the history of philosophical problems (Vollenhoven, 1953).

9 It is a pity that another outstanding French philosopher, Jean Brun of the University of Dijon who was also a reformed Christian and wrote extensively on Christianity and philosophy (cf. Brun, 1988), never took the time to explore reformational philosophy properly and to interact with it (Brun, 1986). 
gelicals, the theological faculties of Vaux-sur-Seine (multi-denominational - Paris area) and Aix-en-Provence (reformed - Marseille area) remain the best outposts of theological reflection.

One of the first traces of reformational scholarship can be found in the writings of Auguste Lecerf (1872-1943), a man of remarkable personality, 10 from Paris. The third chapter of his famous Introduction à la dogmatique réformée (Lecerf, 1938) deals with "Calvinism and philosophy". There the reader may be surprised to discover that long before Dooyeweerd lectured in France, Lecerf (1938:41) mentions "les philosophes réformés Dooyeweerd et Vollenhoven" and shows familiarity with their ideas. Even more surprising is the fact that he discussed the two reformational philosophers before 1938, in a series of scattered articles which were published posthumous with the title Calvinist studies (Lecerf, 1949). Those studies were the object of intense dialogue with the famous French philosopher Étienne Gilson (1884-1978) who argued with Lecerf from a Roman Catholic point of view, in his Christianity and philosophy (Gilson, 1936). With this, reformational thinking was brought to the attention of the "top level" philosophers of France.

It was Pierre Charles Marcel (1910-1992), a student and "fervent disciple" of Lecerf, who established an even more solid relationship with the Dutch reformational movement. Marcel studied at the Free University of Amsterdam during 1937-1938 and later dedicated two doctoral theses (Marcel, 1956; 1960) to the philosophy of Dooye-

10 The father of Auguste Lecerf was an atheist who participated to the revolutionary experience of the Paris' Commune in 1871 and later had to find shelter in England for political reasons. There he married a woman of Italian descent who, according to Courthial, "rarely ever mentioned the name of God". Still an adolescent, for curiosity, one day Auguste entered a church during a service, and when the pastor asked whether anyone would feel ready to give his life to Christ, he felt he was called. Back in Paris, a few years later, he found among the second-hand books of a "bouquiniste" in the Paris' "quai" (the waterfront along the Seine river), a copy of Calvin's Institution, which he bought. At the age of seventeen (to the disappointment of his parents) he asked to be baptised. A few years later he was already a reformed minister. While completing his theological studies he managed to resist the liberal opinions of his lecturers. Eventually, he became the head of the Theological Faculty of Paris. Even more important, the "last of the Calvinists" (as initially he had been ironically called) became the leading figure of a large movement returning to the sources of a truly reformational life view. To support this movement Lecerf also founded the Societé Calviniste de France. 
weerd.11 The two theses were presented to the Faculté de Théologie de Montpellier.

Marcel was a towering figure among French evangelical-reformed theologians. As editor (or co-editor) of La revue réformée (which he himself founded in 1950) he promoted the publication of several of Dooyeweerd's articles. At the same time he (Marcel, 1937; 1981) contributed to the development of reformational scholarship via the pages of Philosophia reformata. Since the middle 1950s, and until 1991, his name appeared in the list of vaste medewerkers (close collaborators) of this journal.

Last but not least, he cooperated with Jan Dengerink (professor of Reformational Philosophy at Utrecht and Groningen) to the establishment of the International Association for Reformed Faith and Action (IARFA) which played a significant role for the promotion of reformational principles all over the world. This was done especially through conferences and through an excellent (popular) journal: the International reformed bulletin.

Marcel wrote outstanding theological texts (Marcel, 1983) from a truly reformational point of view, even when the times became more difficult for reformational scholars. It is a pity that, due to the language barrier, his writings could not be appreciated by a larger international public. As the reformational movement in the 1970s was struggling with a few theological problems and recognised its need for more "theological expertise" (Zylstra, 1975:32), it is also a pity that this skilled theologian could not participate more directly in those debates. 12 Even today, his name is not often mentioned among those who contributed to the elaboration of reformational theology. 13

11 The title of the 1956 thesis is: The transcendental critique of theoretical thought: prolegomena to the philosophy of the idea of law of Herman Dooyeweerd. The 1960 thesis has the title: The theory of the law-spheres. Introduction to the theory of the structure of temporal reality within the framework of Herman Dooyeweerd's philosophy of the idea of law.

12 I have in mind the debates concerning the nature of the three "forms" of the Word of God, reported for example in Downs (1974). When Zylstra spoke of insufficient theological competence he was referring to that debate as well.

13 This is often the case: German-speaking reformational authors like A. Varga von Kibed (Munich) or J. Bohatek (Vienna) have surely suffered the language barrier. The same can be said of Afrikaans speaking authors (like H.G. Stoker), 


\section{French responses: the second phase}

\subsection{The vantilian turn}

During the 1970s the French climate became less favourable to the reformational movement. Gradually the precise and deep knowledge of Dooyeweerd's philosophy was replaced by a vague acquaintance with his views. From the late 1960s some sectors of the vantilian movement in the USA gradually distanced themselves from the reformational school. In 1971 with the publication of Jerusalem and Athens (Gehaan, 1971) the disagreements between the two schools became more tangible. The years 1978-1984 are crucial: vantilian and reconstructionist authors gradually gain the centre-stage in the interests and sympathies of the French evangelical theologians. Initially, in several journals they are simply associated to the reformational scholars, but later they seem to "substitute" them (the possible reasons for the "turn" are discussed in Section 7 below). The (more solid, in my opinion) reformational sources are gradually neglected and after 1990 almost completely excluded. No open discussion, debate or publication marked the shift.

Unfortunately, the vantilian movement does not have the resources to support Christian scholarship in an integral way. In a few decades though it has occasionally produced texts which are somehow related to extra-theological issues, its strong points remain mainly in apologetics and dogmatics. For the rest, the movement has to offer interesting insights into theology of science, of politics, of education, some theological philosophy and so on. It is, however, difficult to quote vantilian academics who made relevant contributions outside theology. The movement is therefore, in my opinion, not properly equipped to support the project of Christian scholarship. One crucial reason is that it tries to promote it while remaining on theological grounds (Coletto, 2009a; 2009b).

The reconstructionist movement (which stemmed from the vantilian movement), though providing more extra-theological literature, produced a rather controversial type of Christian scholarship. The movement supports, for example, the application of the Mosaic penal code in modern America, a policy to be eventually exported more internationally. Many scholars argue that (at least in some respects) it is alien even to the Calvinist tradition (Van Til, 1986).

but fortunately English was fairly familiar to Afrikaans-readers and Afrikaans was fairly understandable to Dutch readers. 


\subsection{Voices in the vantilian turn}

A theologian who can be regarded as a typical representative of this second phase is Pierre Courthial (1914-2009). Some among our senior academics may still remember his contribution to a conference held in Potchefstroom (Courthial, 1976). He was interested in the works of Dutch theologians in general (Courthial, 1983), but two specific articles testify of his interest for the neo-Calvinist movement. One article explores Groen van Prinsterer's legacy (Courthial, 1988). The other displays the history of the kuyperian movement from Van Prinsterer to Rushdoony (Courthial, 1980).

My impression is that Courthial (1995) cultivated important reformational intuitions while he also suffered some lack of clarity concerning issues of scholarship and encyclopaedia. Sometimes one has the impression that, in his writings, the reformational movement is regarded as "part of" a (supposedly broader) reconstructionist movement. One may notice for example, that in the article dedicated to neo-Calvinism he labels the latter as "Christian reconstruction". One may also have the impression that the younger reconstructionist movement, in Courthial's opinion, replaces and includes in itself the previous (reformational and vantilian) movements.

Another interesting figure of this period is Aaron Kayayan (19282008), a pastor of Armenian origins living in Paris. In 1976 he started a radio ministry supported by the Christian Reformed Church in North America. It was a French branch of the "Back to God Hour" ministry, which was also designed to reach the many francophone countries of Africa. The ministry, based in Paris, was called Perspectives Réformées and in addition to the radio-broadcasting it published a journal (also called Perspectives réformées) which could be distributed in those countries as well. 14

Quite soon, Kayayan began to show a keen sympathy for the reformational tradition. Even before the beginning of the radio-ministry he

14 The reader should not imagine that journals like La revue réformée, Studi di teologia or Perspectives réformées work/ed according to the system of South African "accredited" journals. In most cases those journals did/do not just accept the submission of articles by whoever author. The publications were selected by an editorial board that promoted certain views. In some cases, articles considered relevant were translated into French or Italian. The point is that the articles appearing in a certain issue, volume or period, reflect the preferences of the board of editors. This is why it is important to find out which authors were published. 
wrote an article to present the philosophy of Dooyeweerd (Kayayan, 1971: The Christian philosophy of Herman Dooyeweerd). He was for many years a "correspondent" of IARFA for France, and contributed to the organisation of the 1978 Conference of Aix-en-Provence.

In 1982 Kayayan and his ministry moved to the United States. The official reason had to do with administrative problems, but unofficially it was known that the French reformed community was not sufficiently supportive of the neo-Calvinist leanings of the ministry. ${ }^{15}$

Whatever the case, if we take for example the volumes 1978-1984 of Perspectives réformées (the "crucial" years of the turn) and search for neo-Calvinist contributors, the following pattern emerges. In 1978 a whole issue is dedicated to a text by Hughes (1978), a scholar of dooyeweerdian sympathies. In 1984 the two schools are mixed, with a preference for reconstructionism. In fact, Rushdoony is present with four short articles (1984a; 1984b; 1984c; 1984d) in the same issue (1984(2)). Spykman (1984) and Schrotenboer (1984) represent the reformational school with one short article each. The following issue $(1984(3)$ ) is entirely dedicated to Rushdoony (1984e), the topic being The reformed apologetics by Cornelius Van Til. A list of publications by Van Til and Rushdoony completes the issue.

This offers a vivid illustration of the vantilian turn. But did Kayayan contribute to such a turn or did he simply adapt to it? Was it perhaps an effect of the move to America? From the introductions he wrote to the different issues of the journal, it seems that his support of Van Til and Rushdoony was quite spontaneous. It is also possible that these editorial choices may be due to the particular nature of this ministry, for which Kayayan needed relatively "accessible" literature, not the deeper studies from the reformational group. It is interesting, however, that the change of attitude occurs exactly at the time in which we have situated the crucial phase of the "vantilian turn". Gradually, and unfortunately, the reformational authors disappeared from the later volumes of Perspectives réformées.

Finally, let us consider the position of Alain Probst, a philosopher from Paris who obtained his doctorate from La Sorbonne with a thesis on dooyeweerdian philosophy by the title: The structure of "Reformed faith and life") which promotes a neo-Calvinist approach. 
created reality (Probst, 1974). Probst studied reformational philosophy at a deeper level than the two above-mentioned pastors. In addition (and this made him a particularly dear friend) he was one of the most eccentric characters among French Calvinists. Our correspondence stretched from 1986 to 1996 and included several personal visits.

"There were quite a few of us", he once wrote "who knew almost "by heart' the five conferences of Dooyeweerd"! (Probst, 1986.) However, he was also an admirer of Van Til. For example he wrote for Studi di teologia an article on the Apologetic and philosophical system in Cornelius Van Til (Probst, 1983b).

Surely he used to argue that the maitres of neo-Calvinist philosophy constituted a single group: Lecerf, Dooyeweerd and Van Til (Probst, 1983a). Yet the question whether this attitude was "genetic or acquired", so to speak, never abandoned me completely. In other words, it was not clear whether this "equalisation" was not a necessary sacrifice in the particular context in which he found himself, a context in which appreciating the vantilian school was more or less "compulsory" and only on that basis one was allowed to mention the dooyeweerdians. Several of the personal letters he wrote after 1990 allude precisely to this problem (e.g. Probst, 1995a). He also noticed how $L a$ revue réformée had taken a "new direction" from the early 1990s. In his view, the new course (I would say: the further exclusion of reformational authors) was also linked to the death of Pierre Marcel in 1992 (Probst, 1995b).

\subsection{Preliminary evaluative considerations}

During the first phase of the vantilian turn reformational philosophy was not totally ignored. On the contrary, important articles were still produced (e.g. Marcel, 1981). The Dutch "missionary" efforts towards France did not stop either, they continued and not only by means of publications. In this context I would like to mention the Conferences organised by the Association for Reformed Faith and Action (IARFA) in Aix-en Provence in 1978 and in Cret Berard (Lausanne area) in 1984.

Unfortunately, however, the climate was already changing. One may observe, for example, that the only French speaker at the 1978 Conference of Aix was André Coste (1978), a physicist working for the Nuclear Energy-Authority in France. The theologians were not contributing. This is an intriguing aspect on which we will return in section 7 . 
Likewise, La revue réformée was abandoning its initial enthusiasm for reformational authors and gradually retired into a theology-only harbour. Authors like Goudzwaard, Schuurman, Wolterstorff and many others who could have been discussed, were simply ignored. Finally, should one consult the tables of contents of the last 15-20 years of La revue réformée, one finds virtually no article by or about reformational scholars. 16 Marcel and Probst were still occasionally published, but the references to their reformational background were, for some reason, very nuanced indeed. Up to now, vantilian and reconstructionist authors "pop up" regularly (in the tables of contents) to remind the audience what the "philosophically correct" direction is. 17

We will be able to offer more evaluative notes after turning our attention to the Italian side of our research.

\section{The infiltration of neo-Calvinism in Italy}

\subsection{Historical background}

The Reformation could not take place in Italy, due to the harsh repression of the counter-reformation. Many Italian ecclesiastical leaders did join the Reformation (e.g. F. Turrettini sr., P.M. Vermigli and others), but often they had to leave Italy and find shelter in countries like Switzerland or France.

The most consistent "remnant" of the reformed faith in Italy is supposed to be the Chiesa Valdese (Waldensian Church), whose headquarters, so to speak, lie on the Italian side of the border with France (Turin area). Its beginnings date back to the twelfth century, when Pietro Valdo started to read the gospel and began preaching in the local language. 18

16 One can mention only a couple of (almost "unavoidable") exceptions in the issue 1995(4) (two articles in commemoration of Dooyeweerd's 100th birth-year). The article by Paul Wells (2007) on "reformational" political theory deals with Calvin and Althusius, but does not mention reformational authors.

17 Interestingly, a series of eight articles was recently published by Jacob Klapwijk (1997; 1999a; 1999b; 1999c; 2000a; 2000b; 2000c; 2000d) in the French academic journal Hokhma, which hosted some neo-Calvinist writings before (e.g. Courthial, 1980).

18 Pietro Valdo (converted about 1150) was the first of a series of candidatereformers (e.g. Jan Huss, John Wycliff) who preceded Luther and Calvin. This is 
The Waldensian Church suffered huge persecutions during the medieval phase of its life and finally joined the Calvinist Reformation, after the synod of Chanforan of 1532 (Conte, 1983). With the revocation of the Edict of Nantes (1685), Louis XIV started the persecution of the Huguenots and convinced Amedeo II of Savoy to do the same with the Calvinists of Piedmont. It is interesting to note that, as a consequence, some of them later emigrated to South Africa! 19

Yet the more recent history of the Waldensian Church is (at least from a doctrinal point of view) less "heroic". Whatever the case, the penetration of neo-Calvinism in Italy occurred without its help. Amazingly, however, neo-Calvinism was introduced in Italy by a few evangelicals who were surely not expected to perform that task. We are speaking about some sectors of a Chiesa dei Fratelli (Church of the Brethren) in Northern Italy, a descendant of those Chiese Libere (Free Churches) which (cf. section 2) are related to the Free Churches of Switzerland. 20 The introduction of neo-Calvinist views in Italy is due especially to the work of Pietro Bolognesi (born 1946).

\subsection{Further focus}

After the Second World War, the churches of the Brethren in Italy were not very sympathetic towards theologians or academics in general. Their members were mostly from the popular class and the emphasis was on communal church governance, personal piety with

why the Waldensian Church regards itself as Mater Reformationis (Mother of the Reformation).

19 Some of the persecuted Waldensians went to the Netherlands (via France) and were later offered to settle in South Africa, to work for the Dutch East India Company. Arriving in South Africa, however, they were no more distinguished from the French Huguenots. The transcription of their surnames resulted in all sorts of misspellings. Most probably, argues Sani (1990:11-19), this is how Viglione became "Viljoen", Botta became "Botha", Lombard/o became "Lombaard" and so on. As a consequence, Sani (1990:11-19) observes, the percentage of Italians in the first settlements of the Cape could have constituted up to $15 \%$ of the initial white population (600-1 500 persons between 16881710). This means that the "volume" of Italian blood in the veins of the present Afrikaner nation may be higher than one would expect!

20 The Italian Fratelli, as Maselli (1974:32 ff.) demonstrates, are not a derivation of the Plymouth Brethren or of the Darbyst movement. Though there have been contacts between these parties, the Italian Brethren were initially influenced by the Swiss Reveil and then had a rather independent development. 
scarce interest for the broader cultural implications of the gospel. The initial contacts with Swiss Calvinism had long been forgotten. 21

Yet during the 1950s and 1960s a few individuals in the area of Bologna developed reformed convictions (at least in their soteriology, but probably in a wider form). Among them, Pietro Bolognesi decided (early 1970s) to complete a course of theological studies in Paris, at the Faculté Libre de Théologie Evangelique de Vaux-surSeine (Paris area). At that stage his initiative was probably unique. He studied under Henri Blocher, and was systematically exposed to reformed-baptist views. He also met the ideas of Dooyeweerd, Vollenhoven and other neo-Calvinist philosophers.

When Bolognesi returned to Italy, he started a missionary work in Padua (1975). He was also one of the lecturers of the Istituto Biblico Evangelico (IBE) in Rome (now IBEI). There he tried to promote the views which he had absorbed in France, especially through the pages of Studi di teologia (old series: 1978-1988), which was then a journal of IBE. Eventually, the reaction from IBE and from the local churches was quite severe and Bolognesi had to withdraw from teaching (1988). This was the loss of an important contact with the young students, the future leaders of several denominations.

What remained was a few, small congregations in the Lombard Plane. The combination of reformed-baptist-brethren doctrines in those churches would surely be considered a bit "eccentric" by orthodox reformed pastors and theologians. Yet, as far as their basic doctrines and their worldview were concerned, they felt they were "reformed". It is in those communities that the project of a new theological centre emerged: the Istituto di Formazione Evangelica e Documentazione (IFED - founded 1988), to be located in Padova (Padua) with Studi di teologia (nuova serie/new series, from 1989) as official journal.

It is especially in those pages that Bolognesi as editor, translated and published several articles promoting a neo-Calvinist type of worldview. Probably IFED's most important contribution towards reformational scholarship was the translation (by the present author) and publication (by Studi di teologia) of the "Five conferences" of Dooyeweerd (1994) with the title: The new task of a Christian philo-

21 The first communities of the Brethren, in several countries, were quite familiar with Calvinist views. In England, for example, Rowdon (1994:4) writes that he "could not find a single arminian among the first Brethren". 
sophy. In addition, the same journal published articles of Probst and Courthial, but also of the more "classical" reformational thinkers, like Hendrik Hart, W.S. Reid, Calvin Seerveld, Hans Rookmaker, Jan Dengerink, Hebden-Taylor or Edward Fackerell.

At the same time, Studi di teologia published a wide range of vantilian authors: Van Til himself and often John Frame, Poythress and Edgar. The reconstructionists Rushdoony and Bahnsen appeared as well. Gradually, a small group of people acquainted with (or at least aware of) neo-Calvinist thinking was growing within and around IFED. Apart from the present author, one may mention the names of Paul Finch, and later Leonardo De Chirico and Giuseppe Rizza.

\subsection{The vantilian turn in Italy: a déjà vu.}

Unfortunately, once again the inclination towards exclusive monopoly (to the detriment of reformational authors) presented itself in Italy as well. The vantilian "turn" in Italy coincides with the French turn, though its effects were a bit delayed. The first signals of a change of attitude started after a visit to the Netherlands by Bolognesi, during which he attended the second Symposium (1982) of the Society for Reformational Philosophy.

Like the French developments, slowly but surely the vantilian turn took hold in Italy. True, an important text by Dooyeweerd (1994) was still published for the first time in Italian and introduced to the evangelical public. However, the editorial presentation by Bolognesi made it clear that it was not the direction to go. The following issue of Studi di teologia was finally dedicated to the true hero, Cornelius van Til. 22 As it happened with La revue réformée, vantilian and reconstructionist authors continued to be published, while the dooyeweerdian authors disappeared $\mathbf{2 3}$ around 1996, the year in which, due to disagreement about IFED's policies, Coletto decided to leave IFED and Padua.

\subsection{Other contributions from Italy}

Apart from IFED, one can notice a few other traces of interest for dooyeweerdian scholarship in Italy. (Interestingly, all the authors

22 Studi di teologia (new series), 7(1), 1995, issue n. 13.

23 Up to the present, the only exception is an article by Schrotenboer (2002). 
mentioned in this section are members of the Fratelli). 24 One of the earliest traces dates back to 1975, when Massimo Rubboli, then professor at the University of Florence, wrote an interesting essay with the title: The role of religion in Herman Dooyeweerd's philosophy (Rubboli, 1975). Later on, he also spent one year at the Institute for Christian Studies in Toronto. He does not regard himself as a neo-Calvinist thinker (Rubboli, 1987), but it is interesting that he knew about that particular institute and studied there.

On the spur of Rubboli's work a student from Parma, Paola Pagani, wrote a thesis at the University of Bologna with the title: Philosophy and religion in Herman Dooyeweerd's thought (Pagani, 1985). In more recent times G.C. di Gaetano has presented a thesis at the University of Chieti with the title: The Christian philosophy of Herman Dooyeweerd (e.g. Di Gaetano, 1995), which was followed by other articles (Di Gaetano, 1999) 25 and one paper presented in English at the 2005 Symposium of the Society for Reformational Philosophy in the Netherlands (Di Gaetano, 2005). This article is placed in Steve Bishop's website for reformational philosophy (cf. Di Gaetano, 2005) and it offers further information on the interaction of a few Italian academics with the School of Plantinga, Wolterstorff, Alston and others. The fact that this article is available on the internet opens another chapter of this history, and brings new hopes with it. In fact, with diffused access to internet it may be possible that the contact with neo-Calvinist ideas and circles might be facilitated even for individuals living in "previously disadvantaged" areas.

\section{Reflections and questions}

Having detected some of the few "footprints" of the neo-Calvinist movement in France and Italy, a few reflections are in order. The kuyperian movement was split, unfortunately, to the detriment of its reformational branch which had first introduced reformational philosophy in these two countries. What can the causes be? What can be learnt? Apart from Italy and France, I trust the following notes could be relevant in other contexts as well.

24 The majority of the Italian Assemblies of the Fratelli, however, did not welcome the neo-Calvinist turn of some of the Assemblies of the Lombard Plane and from 2006 the latter group withdrew from the Brethren and formed the Evangelical Reformed Baptist Churches of Italy (CERBI). It reminds one of the lack of support experienced by Kayayan's ministry in his own denomination.

25 The translated title reads: Who's the man: rediscovering the Dutch philosopher Herman Dooyeweerd (Di Gaetano, 1999). 
Perhaps one should start by noticing that the vantilians were mainly theologians and pastors. The latter, often feeling "on top" of the Christian enterprise (especially in countries where protestantism is a small minority-group), were often suspicious of organised Christian action "outside" the (institutional) church, suspicious of non-ecclesiastical leaders and of extra-theological studies.

In addition, pastors and theologians sometimes reject a lifeview which is more integral and biblical because they are used to worldviews dominated by the nature-grace dualism. In a recent article I (Coletto, 2009a:31-33) tried to show how a vantilian worldview is often prisoner of a nature-grace dialectics, for example when it comes to theorising about and practicing Christian scholarship. According to an old diagnosis by Vander Stelt (1978:220-270), the roots of the problem lie in the influence of Scottish common-sense realism, which afflicted Presbyterian North American theology from the beginnings. Van Til opposed several tenets of Scottish realism, but Vander Stelt hints that his approach may still be affected by the same disease.

On the other hand, however, one may ask whether the lacunae are all on the side of the vantilians. Perhaps the reformational group uses a type of language which is not so adequate. It appeals to abstract concepts which are not easy for everyone to grasp. The vantilians, on the contrary, keep speaking a language which is more familiar to theologians and pastors. It is the language of the Bible, of the quoted verses: they tend to refer to the biblical basis justifying their positions.

To this argument, however, one may object that when reformational thinking is presented in more "biblical" and accessible language, it is sometimes equally neglected or opposed. I have especially in mind the contribution of B.J. van der Walt, who has done a tremendous work to popularise reformational ideas. This issue reminds one of the gospel words: "we played the flute for you and you did not dance. We sang a dirge and you did not mourn" (Matt. 11:16-17).

Another possible reason for limited reformational success may be that the vantilians are perceived as more orthodox. Perhaps the debates over the word of God in the early 1970s created the impression that the doctrinal orthodoxy of the reformational movement was weak. Yet it is difficult to imagine that this may still be a serious obstacle. The reformational movement might have shown some 
inclination to explore new theological avenues, but it cannot, in my opinion, $\mathbf{2 6}$ be considered as particularly heterodox. And then, is Rushdoony so orthodox? Why is the proposal to execute adulterers or blasphemers in the present dispensation not perceived as problematic? One has the impression that there is something "mysterious" about these issues and that behind a formal recognition of the merits of the reformational movement, there may remain some sort of hidden hostility. Perhaps a special effort should also be made to understand the real roots of this eventual hostility.

Ironically, yet sadly, after marginalising other members of the neoCalvinist family, the vantilians have often been marginalised in their own denominations, both in France and Italy (cf. fn. 24). On the moment they have retreated into a few safe harbours, but there is no forecast of big advances or of significant contributions in extratheological fields.

It is my impression that the reformational "party" has maintained a more loyal, inclusive and open attitude. But perhaps it is not yet sufficiently sensitive to the difficulties of communication. This may be particularly true of the communication with theologians and pastors. It is astonishing to realise, for example, that one of the most effective answers to Van Til's (1971:89-127) very fundamental objections to Dooyeweerd's philosophy lies untranslated in an old issue of the Dutch academic journal Radix (Griffioen, 1988). A simple translation into English would have given the new generation of vantilians, in many countries, a chance of reconsidering the reformational position.

I would like to conclude this section with a question which is probably the most important one: would it be possible for the future, to think and act in more "ecumenical" ways? Would it ever be possible, for the neo-Calvinist families, to be united on the great deal they have in common rather than insisting on what divides?

\section{Conclusion}

In a sense the history of the neo-Calvinist movement in France and Italy is not one of success, especially when one considers the reformational branch. Nevertheless, one should express one's thankfulness for the results that could be achieved. After all, there is something to mention in a context in which, numerically speaking, the 
protestant community is rather marginal. And then, is this present article not written by an Italian philosopher in the reformational tradition? We have also noticed that even today a few authors keep alive the flame of neo-Calvinist thinking both in Italy and France. To achieve better results, however, I believe a more cooperative attitude would be necessary.

\section{List of references}

BRUN, J. 1986. Letter to R. Coletto: 27 Oct. 1986.

BRUN, J. 1988. Philosophie et Christianisme. Paris: Editions du Beffroi/L'Age d'Homme.

COLETTO, R. 2009a. Christian scholarship within reformed circles. Acta academica, 41(3):16-41.

COLETTO, R. 2009b. Strategies towards a reformation of the theology-based approach to Christian scholarship. In die Skriflig, 43(2):291-313.

COLETTO, R. 2010. The role of the Bible in reformational philosophy: historical and systematic notes. In die Skriflig, 44(3). (To be published.)

CONTE, G. 1983. Chanforan 1532-1982: l'adhésion du mouvement vaudois à la Réforme. La revue réformée, 34(1):13-24.

COSTE. A. 1978. Living the Christian hope in a condemned world. International reformed bulletin, 21(n. 73):6-11.

COURTHIAL, P.C. 1976. Threats to the Christian character of the Christian institution. (In Christian higher education: the contemporary challenge. Proceedings of The First International Conference of Reformed Institutions for Christian Scholarship. Potchefstroom: PU for CHE. Institute for Reformational Studies. p. 44-56.)

COURTHIAL, P.C. 1980. Le mouvement réformé de reconstruction chrétienne. Hokhma - revue de reflection théologique, 5(2):44-70.

COURTHIAL, P.C. 1983. Le Christ et la culture selon Klaas Schilder. La revue réformée, 34(1):37-45.

COURTHIAL, P.C. 1988. Un critique réformé de la revolution francaise: Guillaume Groen Van Prinsterer (1801-1876). La revue réformée, 39(3):29-39.

COURTHIAL, P.C. 1995. Le combat de la foi aujourd'hui. La revue réformée, 46(1):1-8.

DE GAAY FORTMAN, W.F., ed. 1965. Philosophy and Christianity: philosophical essays dedicated to Professor Dr. Herman Dooyeweerd. Amsterdam: North-Holland.

DENGERINK, J.D. 1994. Herman Dooyeweerd (1894-1977) filosofo cristiano, riformato, ecumenico. Studi di teologia (nuova serie), 6(2):103-120.

DI GAETANO, G.C. 1995. La filosofia cristiana di Herman Dooyeweerd. Chieti: Università di Chieti (Tesi di Laurea).

DI GAETANO, G.C. 1999. Chi è l'uomo: riscoprire il filosofo olandese Herman Dooyweweerd. Prospettiva persona, 8(2?):16-23. 
DI GAETANO, G.C. 2005. The reception of reformed epistemology in the Italian philosophical context. http://www.allofliferedeemed.co.uk/further information.htm Date of access: 15 Feb. 2010. Cf. also http://home. wxs.nl/ srw/is2005/speakers/ workshops.html Date of access: 16 Feb. 2010.

DOOYEWEERD, H. 1947. Introduction to a transcendental criticism of philosophic thought. The evangelical quarterly, 10(1):42:51.

DOOYEWEERD, H. 1948. Introduction à une critique transcendentale de la pensée philosophique. (In Mélanges philosophiques. Bibliothèque du $X$ Congrés International de Philosophie. Vol. 2. Amsterdam: Veen S.A. p. 70-82.)

DOOYEWEERD, H. 1954a. Le problème de la philosophie chrétienne: une confrontation de la philosophie blondélienne avec la nouvelle philosophie réformée en Hollande. Philosophia reformata, 19(1):49-76.

DOOYEWEERD, H. 1954b. La sécularisation de la science. La revue réformée, 5(1-2):138-155.

DOOYEWEERD, H. 1958a. Philosophie et théologie. La revue réformée, 9(3):48-60.

DOOYEWEERD, H. 1958b. Mouvements progressifs et régressifs dans I'histoire. La revue réformée, 9(4):1-13.

DOOYEWEERD, H. 1959. Cinq conférences. La revue réformée, 10(3):3-76.

DOOYEWEERD, H. 1994. II nuovo compito d'una filosofia cristiana. Studi di teologia (nuova serie), 6(2):121-198.

DOWNS, H.L. 1974. The distinction between power-word and text-word in recent reformed thought: the view of Scripture set forth by some representatives of the philosophy of the law-idea. Nutley: Presbyterian \& Reformed Publishing.

ELLUL, J. 1965. Réflexions sur le droit comme représentation. (In De Gaay Fortman, W.F., ed. Philosophy and Christianity: philosophical essays dedicated to Professor Dr. Herman Dooyeweerd. Amsterdam: NorthHolland. p. 249-261.)

FREEKE, H. 2001. La vita e l'opera di Groen Van Prinsterer. Studi di teologia (nuova serie), 13(2):127-137.

GEHAAN, E.R., ed. 1971. Jerusalem and Athens. Nutley: Presbyterian \& Reformed Publishing.

GILSON, E. 1936. Christianisme et philosophie. Paris: Vrin.

GRIFFIOEN, S. 1988. Communicatie als problem: een critische vergelijking van enkele typen van wijsgerige apologetiek. Radix, 13(1):129-139

HUGHES, Ph. E. 1978. La foi chrétienne et le problème des origines. Perspectives réformées, 7(4):87-91.

KAYAYAN, A. 1971. La philosophie chrétienne de Herman Dooyeweerd. La revue réformée, 22(1):1-26.

KLAPWIJK, J. 1997. La philosophie d'après Calvin et le néo-calvinisme. Hokhma - revue de reflexion théologique, 22(1):44-68.

KLAPWIJK, J. 1999a. A la recherche d'une philosophie ouverte. Prologue: entre étonnement et perplexité. Hokhma - revue de reflexion théologique, 24(1):1-5.

KLAPWIJK, J. 1999b. A la recherche d'une philosophie ouverte: W. Dilthey et I'historicisme. Hokhma - revue de reflexion théologique, 24(1):6-23. 
KLAPWIJK, J. 1999c. A la recherche d'une philosophie ouverte: Martin Heidegger et la philosophie de l'existence. Hokhma - revue de reflexion théologique, 24(2):1-14.

KLAPWIJK, J. 2000a. A la recherche d'une philosophie ouverte: William James et le pragmatisme. Hokhma - revue de reflexion théologique, 25(1):1-15.

KLAPWIJK, J. 2000b. A la recherche d'une philosophie ouverte: Ludwig Wittgenstein et la philosophie analitique. Hokhma - revue de reflexion théologique, 25(2):1-22.

KLAPWIJK, J. 2000c. A la recherche d'une philosophie ouverte: Herbert Marcuse et le néo-marxisme. Hokhma - revue de reflexion théologique, 25(3):1-15.

KLAPWIJK, J. 2000d. A la recherche d'une philosophie ouverte: epilogue: l'ouverture de la philosophie. Hokhma - revue de reflexion théologique, 25(3):16-25.

KUYPER, A. 1907. La séparation. Journal des débats: 27, Feb.

LECERF, A. 1938. Introduction à la dogmatique réformée. 2 vols. Paris: Je Sers.

LECERF, A. 1949. Études calvinistes. Neuchatel: Delachaux \& Niestlé.

MARCEL, P. Ch. 1937. La conception de la loi chez Duns Scot. Philosophia reformata, 2(1):224-236.

MARCEL, P. Ch. 1956. Le criticisme transcendental de la pensée théorique: prolégomènes à la philosophie de l'idée de loi de Herman Dooyeweerd. Montpellier: Faculté de Théologie Protestante.

MARCEL, P. Ch. 1960. Théorie des cercles des lois: introduction à la théorie de la structure de la réalité temporelle dans le cadre de la philosophie de l'idée de loi de Herman Dooyeweerd. Montpellier: Faculté de Théologie Protestante.

MARCEL, P. Ch. 1981. Calvin et Copernicus. Philosophia reformata, 46(1):1436.

MARCEL, P. Ch. 1983. La parabole des talents: Matthieu 25:14-30. La révue réformée, 34(2):49-54.

MASELLI, D. 1974. Tra risveglio e millennio: storia delle chiese dei Fratelli 1836-1886. Torino: Claudiana.

MEKKES, J.P.A. 1953. Critique transcendentale de la pensée théorique. Proceedings of the 11th International Congress of Philosophy. Amsterdam: North Holland.

MEKKES, J.P.A. 1965. Le temps. (In De Gaay Fortman, W.F., ed. Philosophy and Christianity: philosophical essays dedicated to Professor Dr. Herman Dooyeweerd. Amsterdam: North-Holland. p. 31-56.)

PAGANI, P. 1985. Filosofia e religione nel pensiero di Herman Dooyeweerd. Bologna: Universitàdi Bologna (Tesi di Laurea).

PROBST, A. 1974. Structure de la réalité créée. Paris: Université la Sorbonne. (Unpublished doctoral thesis.)

PROBST, A. 1983a. Qu'est-ce que le néo-calvinisme? La revue réformée, 34(2):67-76.

PROBST, A. 1983b. Sistema apologetico e filosofico in Cornelius Van Til. Studi di teologia (nuova serie), 6(1):47-76.

PROBST, A. 1986. Letter to R. Coletto: 15 Mar. 1986.

PROBST, A. 1995a. Letter to R. Coletto: 20 Feb. 1995.

PROBST, A. 1995b. Letter to R. Coletto: 7 Mar. 1995. 
ROWDON, H.H. 1994. Il problema dell' identità dei Fratelli nella sua prospettiva storica. Studi di teologia (nuova serie), 6(3):1-11.

RUBBOLI, M. 1975. La funzione della religione nel pensiero di Herman Dooyeweerd. (In Babolin, A., ed. II metodo della filosofia della religione. Padova: s.n. p. 281-303.)

RUBBOLI, M. 1987. Letter to R. Coletto: 28 Jan. 1987.

RUSHDOONY, J.R. 1984a. Personnalité de l'homme. Perspectives réformées, 14(2):33-36.

RUSHDOONY, J.R. 1984b. Psychologie ou création? Perspectives réformées, 14(2):33-36.

RUSHDOONY, J.R. 1984c. Un polythéisme moderne. Perspectives réformées, 14(2):78-81.

RUSHDOONY, J.R. 1984d. L'échec des hommes. Perspectives réformées, 14(2):87-91.

RUSHDOONY, J.R. 1984e. L'apologétique réformée de Cornelius van Til. Perspectives réformées, 14(3):7-62.

SANI, G. 1990. Storia degli italiani in Sud Africa: 1489-1989. Edenvale: Zonderwater Block South Africa.

SCHLEMMER, A. 1965. Médicine et unité de l'homme. (In De Gaay Fortman, W.F., ed. Philosophy and Christianity: philosophical essays dedicated to Professor Dr. Herman Dooyeweerd. Amsterdam: North-Holland. p. 377387).

SCHROTENBOER, P.G. 1984. Le fondement inebranlable. Perspectives réformées, 14(2):5-9.

SCHROTENBOER, P.G. 2002. Una prospettiva cristiana della cultura. Studi di teologia (nuova serie), 14(1):5-39.

SPYKMAN. 1984. Quels droits pour l'homme. Perspectives réformées, 14(2):87-91.

VAN TIL, C. 1971. Response by C. van Til. (In Gehaan, E.R., ed. Jerusalem and Athens. Nutley: Presbyterian \& Reformed Publication. p. 89-127.)

VAN TIL, L.J. 1986. The reconstructionist movement: in the calvinist tradition? Pro Rege, 14(3):19-28.

VANDER STELT, J.C. 1978. Philosophy and Scripture: a study in Old Princeton and Westminster Theology. Amsterdam: Free University. (Ph.D. thesis.)

VOLLENHOVEN, D.H. Th. 1953. L'évolution d'Aristote: étude d'histoire de la problématique philosophique. Proceedings of the 11th International Congress of Philosophy. Amsterdam: North Holland.

WELLS, P. 2007. La théorie politique réformationelle et le pacte social. La revue réformée, 58(5):41-66.

ZUIDEMA, S.U. 1953. Conception réformée de la vie. La revue réformée, 10(4):10-28.

ZYLSTRA, B. 1975. Introduction. (In Kalsbeek, L. Contours of a Christian philosophy: an introduction to Herman Dooyeweerd's thought. Amsterdam: Buijten \& Schipperheijn. p. 14-33.) 


\section{Key-concepts:}

church history

Neo-Calvinism in France and Italy, history of reformational movement in France and Italy, history of reformational movement in the Netherlands, history of Vantilian movement in France and Italy, history of

\section{Kernbegrippe:}

kerkgeskiedenis

neo-Calvinisme in Frankryk en Italië, geskiedenis van reformatoriese beweging in Frankryk en Italië, geskiedenis van reformatoriese beweging in Nederland, geskiedenis van Van Til-beweging in Frankryk en Italië, geskiedenis van 